Special issue of the 3rd International Conference on Computational and Experimental Science and Engineering (ICCESEN 2016)

\title{
Investigation of Radiation Shielding Properties of Soda-Lime-Silica Glasses Doped with Different Food Materials
}

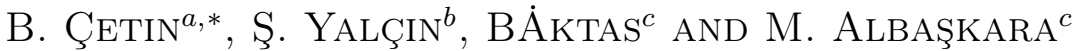 \\ ${ }^{a}$ Amasya University, Physics Department, Amasya, Turkey \\ ${ }^{b}$ Harran University, Physics Department, Sanliurfa, Turkey \\ ${ }^{c}$ Harran University, Mechanical Engineering Department, Sanliurfa, Turkey
}

\begin{abstract}
In this study, radiation shielding properties of soda-lime-silica glasses doped with different food materials such as the egg shell and the peanut shell powders were investigated. Egg shell and peanut shell powders were obtained by grinding of waste shells in an agate mortar. The SLS glass samples with varying egg shell/peanut shell content were produced by melting. The measurements have been performed using the gamma spectrometer, containing a $3^{\prime \prime} \times 3^{\prime \prime} \mathrm{NaI}(\mathrm{Tl})$ detector, and connected to a full featured $16 \mathrm{~K}$ channel Multi Channel Analyzer provided by ORTEC/MAESTRO-32 software.
\end{abstract}

DOI: $10.12693 /$ APhysPolA.132.988

PACS/topics: 29.40-n, 29.40-Mc

\section{Introduction}

Glass is an inorganic material which is found in many products used in daily life. Soda lime silica (SLS) glass is one type of the glass [1]. SLS glass is attractive material due to its insulating properties, good and acceptable mechanical properties, superior chemical resistance and optical transparensy $[2,3]$.

Food waste materials are defined as the undesired materials that may consists of the leftover from the manufacturing process or human usage. Thus these wastes constitute health and environment problem. However, these materials include valuable mineral such as $\mathrm{SiO}_{2}$, $\mathrm{CaO}, \mathrm{K}_{2} \mathrm{O}, \mathrm{Na}_{2} \mathrm{O}, \mathrm{MgO}, \mathrm{Al}_{2} \mathrm{O}_{3}, \mathrm{P}_{2} \mathrm{O}_{5}$, which are used as raw materials for production of glass, ceramic and glass ceramic $[4,5]$.

Glass compositions, when used without concrete compositions, are transparent to visible light. Their structure and properties can be changed considerably by applying changes in the preparation techniques [6].

In recent years, there has been an increasing interest in the development of radiation shielding properties. There is a rich literature on the different studied materials. For example, Singh et al. have investigated the $\mathrm{ZnO}-\mathrm{PbO}$ $\mathrm{B}_{2} \mathrm{O}_{3}$ glasses [7]. Singh et al. have investigated the lead borate glass and bismuth lead borate glass [8]. Akkurt et al. have investigated the concretes containing different aggregates [9]. Akkurt et al. have investigated the concrete containing zeolite [10]. Mavi has investigated the granites [11]. Chanthima et al. have investigated the silicate glasses containing $\mathrm{Bi}_{2} \mathrm{O}_{3}, \mathrm{BaO}$ and $\mathrm{PbO}$ [12]. Tapan et al. have investigated the pumice material [13]. Chanthima and Kaewkhao have investigated the bismuth borosilicate glass [14]. Özavciand Cetin, have investiga-

*corresponding author; e-mail: betulcetin3205@gmail.com ted radiation attenuation coefficients in concretes containing different wastes [15]. Akkurt and El-Khayatt have investigated the effect of barite proportion on neutron and gamma-ray shielding [16]. Çullu and Ertaş have investigated lead mine waste aggregate in concretes [17]. Mutuk at al. have investigated shielding behavior and have analyzed mechanical treatment of cements containing nanosized powders (Nano- $\mathrm{SiO}_{2}, \mathrm{Nano}-\mathrm{Fe}_{2} \mathrm{O}_{3}$, Nano$\mathrm{Al}_{2} \mathrm{O}_{3}$ ) [18]. Akkurt et al. have investigated the influence of chemical corrosion on gamma-ray attenuation properties of barite concrete [19]. Gurler and Akar Tarmm, have investigated radiation shielding properties of some polymer and plastic materials against gamma-rays [20]. Akkurt et al. have investigated gamma ray shielding properties at different energies of concrete containing barite [21, 22].

\section{Materials and methods 2.1 Sample preparation}

SLS glass has been obtained from Trakya Şişecam glass factory. Peanut shell (PS), egg shell (ES) wastes and SLS glass were ground in an agate mortar. Different amounts of the PS waste powders $(0.5,1,3$, and 5 wt.\%) were mechanically homogeneously mixed with the SLS powders in an attritor type mixer at $300 \mathrm{rpm}$ for $1 \mathrm{~h}$. The powders were then pressed at $250 \mathrm{MPa}$ in a single-axis die with a radius of $32 \mathrm{~mm}$, which produced pellets of $32 \mathrm{~mm}$ in diameter and $6 \mathrm{~mm}$ in thickness. The glass samples were prepared by melting the undoped and the PS-doped SLS powders in a graphite mold at $1300^{\circ} \mathrm{C}$ for $2 \mathrm{~h}$ to ensure homogeneity. The molten glass was then quenched in the mold. After quenching, the samples were formed in a square shaped graphite mold at $1100^{\circ} \mathrm{C}$. The formed samples were annealed at $500^{\circ} \mathrm{C}$ for $3 \mathrm{~h}$ and then slowly cooled to room temperature inside the furnace (Fig. 1).

\subsection{Experimental procedure}

Radiation shielding measurements of SLS-food waste have been performed using the gamma spectrometer of 


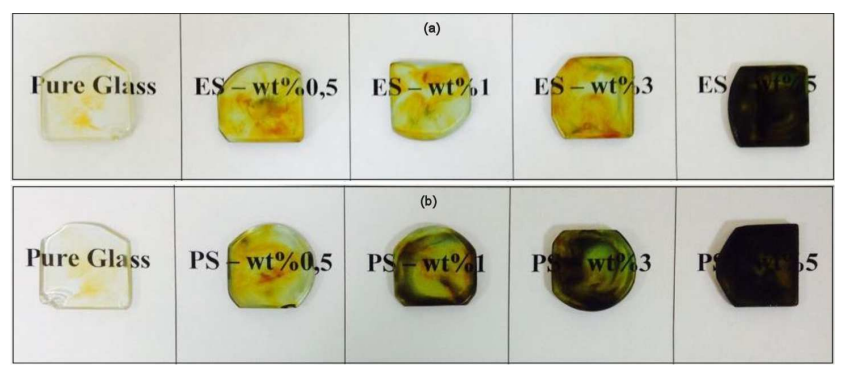

Fig. 1. Glass materials (a) SLS-ES (b) SLS-PS.

the Amasya University Radioactive Research Lab., containing a $3^{\prime \prime} \times 3^{\prime \prime} \mathrm{NaI}(\mathrm{Tl})$ detector, coupled to a digital spectrum analyzer (DSPEC LF), connected to the $16 \mathrm{k}$ channels Multi Channel Analyzer (MCA) provided by ORTEC hardware, controlled by MAESTRO32 software (Fig. 2).

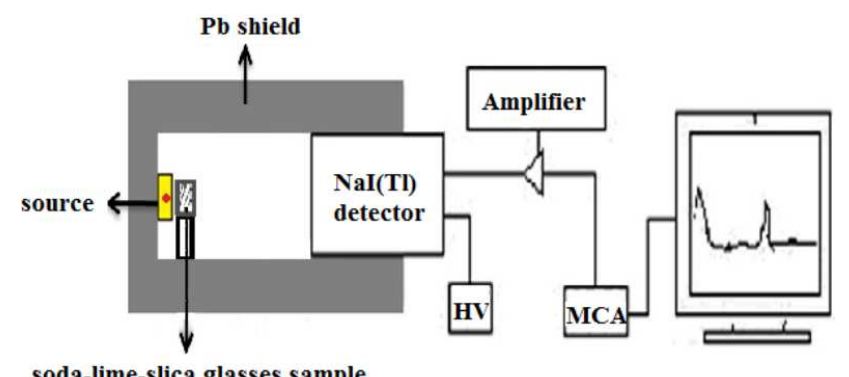

Fig. 2. Schematic view of the experimental setup.

The spectrometer has been calibrated using gammaray sources of ${ }^{137} \mathrm{Cs}$ and ${ }^{60} \mathrm{Co}$, which produce $\gamma$-ray energies of 662,1173 and $1332 \mathrm{keV}$, respectively.

The linear attenuation coefficients Eq. (1) have been evaluated using values of $I$ and $I_{0}$, which are the measured count rates of the detector, with and without the absorber, respectively. According to the Beer-Lambert's law

$$
I=I_{0} \mathrm{e}^{-\mu x}
$$

where $I_{0}$ and $I$ are the initial and transmitted intensities; $\mu$ is the linear attenuation coefficient of the material; $x$ is the penetration depth.

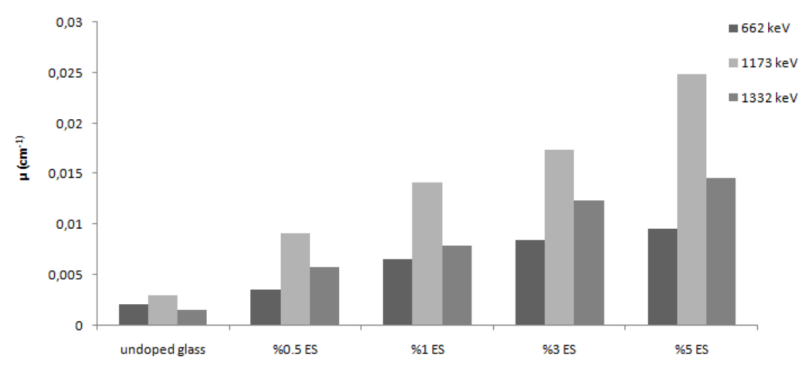

Fig. 3. The measured $\mu$ for the soda-lime-silica glasses doped with the egg shell powders at energies of 662 , 1173 and $1332 \mathrm{keV}$.

The linear attenuation coefficients $\mu$ for the sodalime-silica glasses have been obtained for 662,1173 and

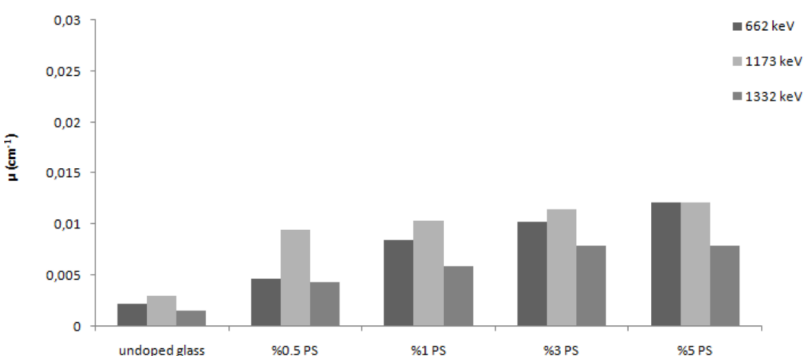

Fig. 4. The measured $\mu$ for the soda-lime-silica glasses doped with the peanut shell powders at energies of 662 , 1173 and $1332 \mathrm{keV}$.

$1332 \mathrm{keV}$ gamma rays and the results are displayed in Figs. 3 and 4 .

It can be concluded from this work that the soda-limesilica glasses doped with the egg shell are more suitable than those with peanut shell as the radiation shielding materials.

\section{Acknowledgments}

This work has been supported with Harran University project, number 14170. Authors thank Trakya Şişecam glass factory for SLS glass material.

\section{References}

[1] T. Wongsing, J. Kaewkhao, P. Limsuwan, C. Kedkaew, Proced. Eng. 32, 807 (2012).

[2] E.M.A. Khalil, F.H. Elbatal, Y.M. Hamdy, H.M. Zidan, M.S. Aziz, A.M. Abdelghany, Phys. B: Cond. Matt. 405, 1294 (2010).

[3] W. Kaewwiset, J. Kaewkhao, P. Limsuwan, Asian J. Energy Environ. 11, 37 (2010).

[4] I.A. Cornejo, S. Ramalingam, J.S. Fish, I.E. Reimanis, Am. Ceram. Soc. Bull. 93, 24 (2014).

[5] A.H.M. Noor, S.H.A. Aziz, S.S.A. Rashid, M.H.M. Zaid, Z.N. Alassan, K.A. Matori, J. Solid St. Sci. Technol. Lett. 16, 1 (2015).

[6] E.-S.A. Waly, M.A. Fusco, M.A. Bourham, Ann. Nucl. Energy 96, 26 (2016).

[7] H. Singh, K. Singh, L. Gerward, K. Singh, H.S. Sahota, R. Nathuram, Nucl. Instrum. Meth. Phys. Res. B 207, 257 (2003).

[8] N. Singh, K.J. Singh, K. Singh, H. Singh, Nucl. Instrum. Meth. Phys. Res. B 225, 305 (2004).

[9] I. Akkurt, C. Basyigit, S. Kilicarslan, B. Mavi, A. Akkurt, Cement Concrete Compos. 28, 153 (2006).

[10] I. Akkurt, H. Akyıldırım, B. Mavi, S. Kilincarslan, C. Basyigit, Radiation Measurements, 45, 827 (2010).

[11] B. Mavi, Ann. Nucl. Energy 44, 22 (2012).

[12] N. Chanthima, J. Kaewkhao, P. Limsuwan, Ann. Nucl. Energy 41, 119 (2012).

[13] M. Tapan, Z. Yalçın, O. İçelli, H. Kara, S. Orak, A. Özvan, T. Depci, Ann. Nucl. Energy 65, 290 (2014). 
[14] N. Chanthima, J. Kaewkhao, Ann. Nucl. Energy 55, 23 (2013).

[15] S. Özavc1, B. Çetin, Acta Phys. Pol. A 130, 316 (2016).

[16] I. Akkurt, A.M. El-Khayatt, Ann. Nucl. Energy 51, 5 (2013)

[17] M. Çullu, H. Ertaş, Construct. Build. Mater. 125, 625 (2016).
[18] H. Mutuk, T. Mutuk, H. Gümüş, B. Mesci Oktay, Acta Phys. Pol. A 130, 172 (2016).

[19] I. Akkurt, H. Akyıldırım, F. Karipçin, B. Mavi, J. Saudi Chem. Soc. 16, 199 (2012).

[20] O. Gurler, U. Akar Tarım, Acta Phys. Pol. A 130, 236 (2016).

[21] I. Akkurt, H. Akyildirim, B. Mavi, S. Kilincarslan, C. Basyigit, Prog. Nucl. Ener. 52, 620 (2010).

[22] I. Akkurt, Ann. Nucl. En. 36, 1702 (2009). 